\title{
Preferences and Level of Satisfaction with Eyelash Beauty Treatments
}

\author{
Tae II Kwon ${ }^{1}$, Hye Soon $\mathrm{Heo}^{2 *}$ \\ ${ }^{1}$ Department of Public Health and Environment, Kosin University, Busan, Korea \\ ${ }^{2}$ Department of Wedding Industry, Dong-Pusan College, Busan, Korea
}

*Corresponding author: Hye Soon Heo, Department of Wedding Industry, Dong-Pusan College, 60 Unbong-gil, Haeundae-gu, Busan 48000 , Korea

Tel.: +82515403783

Fax: +82515403643

Email: jinah2s@naver.com

Received March 11, 2017

Revised December 5, 2017

Accepted January 4, 2018

Published June 30, 2018

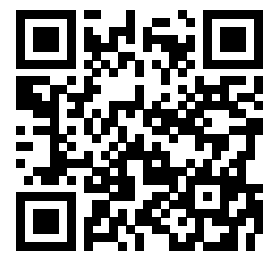

\begin{abstract}
Purpose: This study examines the preferences and level of satisfaction associated with different eyelash beauty treatments. Methods: We used IBM SPSS Statistics V22.0 to analyze the survey results of 257 unmarried college students in their twenties, living in Busan, South Korea. We performed a frequency analysis of eyelash preferences and chi-square $\left(X^{2}\right)$ cross analysis to determine the levels of satisfaction for each eyelash beauty treatment. Results: As a result of examining eyelash beauty preferences, we found the most important skill of an eyelash designer to be eyelash retention. The most preferred eyelash treatment characteristics are silk hair type, $\mathrm{JC}$ curl, thickness of 0.05-0.07 mm, and length of 10-11 mm. The preferred eyelash technique is hair root protection. Most participants were satisfied with their eyelash treatment and the reason for seeking eyelash treatment was to make their eyes look well-defined. Ultimately, the main purpose of eyelash beauty treatment is to satisfy one's own self-image. Types of hair, curl, thickness, length, and technique are all statistically relevant in the determination of the amount of satisfaction associated with an eyelash beauty treatment. Conclusion: In order to make our findings more effective, we propose a study of customer preference and satisfaction for various ages and regions.
\end{abstract}

Keywords: Eyelash, Eyelash design, Eyelash beauty, Preferences, Satisfaction

\section{Introduction}

인간은 수많은 다른 사람과 관계를 형성하며 살아간다. 대인 관계에 있어서 외모는 다른 사람의 관심이나 평가의 대상이 될 수 있으므로, 자신의 경쟁력을 높이기 위하여 많은 노력을 들여 외모를 관리하기도 한다. 메이크업은 외모 관리에 직접 관련되 며 매우 중요하고 효과적인 수단이며 작은 변화로도 얼굴 이미 지를 쉽게 변화시킬 수 있을 만큼 민감하기도 하다(Ahn \& Cho, 2006). 메이크업에 있어서 특히, 눈 화장이 차지하는 비중은 매 우 크고(Lee \& Kuh, 2003; Song \& Min, 2014), 눈은 얼굴 전 체의 이미지와 분위기를 좌우한다(Kang \& Park, 2016).

눈 화장의 기원은 B.C. 3000 년경 이집트에서 코올 $(\mathrm{Kohl})$ 을 이용하여 눈썹과 아이라인을 강조하는 것에서 시작되었다(Lee et al., 2001). 인조 속눈썹은 첩모라고도 하며(Lee \& Han, 2017), 18세기초에는 쥐의 피부로 인조 속눈썹을 만들어 아교로
붙여 속눈썹을 강조하기도 했다(Go, 2015). 19세기부터는 인조 속눈썹이 대중화되었고(Choi et al., 2004), 근대에는 동물의 털 로 인조 속눈썹을 만들어 붙이기 시작하였다(Go, 2015).

현대에 와서는 인조 속눈썹이 다양하게 발전해 왔다. 아이 메 이크업이 번지고 지워져 수시로 수정해야 하는 번거로움을 보완 하기 위해, 속눈썹 연장 기법과 속눈썹 증모 기법, 속눈썹 펌 등 의 지속 가능한 메이크업인 속눈썹 기법들이 선풍적인 인기를 얻 고 있다(Jang \& You, 2012; Lim, 2007). 속눈썹 연장 기법은 화장의 시간을 단축시켜줄 뿐만 아니라, 마스카라나 인조 속눈썹 없이 깊고 진한 눈매를 연출할 수 있으며(Seol, 2008), 동공을 강조하는 연장 디자인으로 강아지 눈과 같이 귀여운 눈매를 연출 할 수도 있고, 눈꼬리를 강조하여 고양이 눈과 같이 섹시하고 요 염한 눈매를 연출할 수도 있다(Kwon, 2012). 속눈썹은 단모이 므로(Kim et al., 2001; Kwon et al., 2012), 속눈썹 미용으로 입체적인 얼굴 라인과 매력적인 옆 얼굴 선을 표출할 수 있다. 
속눈썹 연장 시술은 개인의 눈매와 자신에게 맞는 속눈썹 컬러 (quoted in Kim, 2009)와, 속눈썹 컬과 길이, 풍성도(숱)를 선 택하여 더욱 매력적인 눈을 완성시켜주는 필수 아이템이며, 개 인의 취향을 반영할 수 있는 훌륭한 속눈썹 관리법이다(Lee \& Kuh, 2003; Song \& Min, 2014).

속눈썹 연장은 자연 화학 섬유로 만들어진 합성 속눈썹 (Amano \& Nishiwaki, 2013)과 모의 염색에 기인한 부작용 (Jamieson, 1933), 속눈썹 연장을 위한 접착제와 시약의 침투, 제거과정 등에 의한 피부 알레르기와 출혈 등의 안질환(Amano et al., 2012)이 유발될 수 있으므로 주의해야 한다. 속눈썹의 성 장주기는 3-5개월 정도이므로(Kwon et al., 2012), 자연모의 탈모기에 인조모가 함께 떨어져 나온다.

속눈썹 연장을 위해 사용되는 모의 소재는 일반적으로 원사이 며, 실크 모는 원사를 실크처럼 가볍게, 단백질 모는 가 속눈썹 에 단백질을 추가하여 가공한 것이고, 밍크 모는 실제 밍크 털 을 소독, 탈색, 염색 등 여러 과정을 거쳐 가공, 처리하여 밍크처 럼 부드럽게 속눈썹을 만든 것이다. 이 외에도 돼지, 토끼, 오소 리 털 등 동물의 모를 이용하여 가공, 처리하기도 한다. 성분 확 인이 안된 동물의 털을 잘못 가공하여 사용할 경우 치명적인 안 질환과 피부질환을 일으킬 수 있으므로 주의하여야 한다. 인모 는 사람의 실제 머리카락을 가공 처리하여 만들었으며, 이 외에 도 자연스러운 내추럴 모, 풍성한 눈썹을 연출하는 볼륨업 모와 강력하고 광택이 뛰어난 그래머 모, 레미 모(단백질)등의 특수모 도 다양하게 출시되고 있다(Kang \& Park, 2016; Kim et al., 2017).

속눈썹 컬의 형태도 다양하게 분류되는데, 가장 완만한 형태의 $\mathrm{J}$ 컬, 컬이 많이 올라가서 컬이 센 형태의 $\mathrm{C}$ 컬, 이 두 가지 컬의 장점을 살린 $\mathrm{JC}$ 컬이 대표적이다. 2-4가닥의 속눈썹이 미리 가

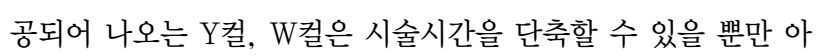
니라 더욱 풍성한 속눈썹 연출이 가능하다. 속눈썹이 많이 올라 가 인위적이고 더욱 인형 같은 눈매 연출을 원할 때는 $\mathrm{D}$ 컬, $\mathrm{CC}$ 컬, $\mathrm{U}$ 컬이 효과적이고, $\mathrm{L}$ 컬, $\mathrm{L}+$ 컬은 뷰러를 한 것처럼 모가 한 번 더 꺾여 있는 형태의 속눈썹이다. I컬은 거의 일자형에 가까운 속눈썹이고, J컬보다 더욱 완만한 형태의 속눈썹이다(Kang \& Park, 2016; Kim et al., 2017).

인조 속눈썹의 굵기는 0.05-0.20 mm로 개인의 자연 속눈썹 의 상태에 따라 선택하여 사용하며, 인조 속눈썹의 길이는 각 개 인의 취향에 따라 4-20 $\mathrm{mm}$ 까지 다양하게 선택하여 사용한다. 또한, 언더의 속눈썹은 일반적으로 $6 \mathrm{~mm}$ 를 사용한다(Kang \& Park, 2016). 속눈썹 연장기법은 원-투-원 기법, 한 손(onehandling) 교정기법, 더블트리플 기법, 모근 보호 기법, D기법 $(3 \mathrm{D}, 5 \mathrm{D}, 6 \mathrm{D}, 9 \mathrm{D})$ 등이 있다. 최근 가장 유행하는 미용업종으 로 속눈썹 연장이 떠오르고 있으며, 이에 따라 많은 사람들이 속 눈썹 미용시술을 받을 뿐만 아니라, 속눈썹 연장의 다양한 기
술(Gandelman, 2005)과 독창적이고 획기적인 제품(Umar, 2015)에 대해서도 급격하게 관심이 증가되고 있으며(Cohen, 2010), 속눈썹 미용은 여성들의 메이크업에 필수적인 역할을 담 당하게 되었다(An, 2005).

따라서 본 연구는 떠오르는 속눈썹 미용의 선호도와 만족도를 조사하고 선호도에 따라서 시술 후의 만족도를 조사, 분석하여 더욱 효과적으로 현장에서 고객의 욕구와 만족도를 파악하는데 목적이 있다.

\section{Methods}

\section{1. 연구대상 및 자료수집}

속눈썹 미용에 대한 선호도 및 만족도에 관한 연구를 위하여 부산 지역에 거주하는 20 대 미용전공 대학생으로 속눈썹 미용 경험이 있는 미혼 여성을 대상으로 편의 표집하였다. 2016년 9 월 5 일부터 9 월 20 일까지 총 300 명을 대상으로 설문지를 배포 하여 자기 기입식으로 작성하였으며 총 257 부가 최종 자료 분석 에 사용되었다.

\section{2. 연구내용}

본 설문지의 내용은 선행연구를 바탕으로 수정, 보완하여 연구 자가 재구성하였다. 눈썹 미용에 관한 선호도 6 문항, 속눈썹 미 용 시술 후 만족도 6 문항, 총 12 문항으로 구성하였다.

\section{3. 자료분석}

본 연구를 수행하기 위한 실증분석은 모두 유의수준 $5 \%$ 에 서 검증하였으며, 수집된 자료의 통계처리는 데이터 코딩(date coding)과 데이터 클리닝(date cleaning) 과정을 거쳐 통계 프 로그램 SPSS (WIN 22.0; IBM, USA)를 사용하였다. 자료분석 방법은 속눈썹 미용 선호도와 만족도를 알아보기 위하여 빈도분 석을 실시하였고 시술 후 만족도의 차이를 알아보기 위하여 카이 제곱 검정 $\left(\chi^{2}\right)$ 교차분석을 실시하였다.

\section{Results and Discussion}

\section{1. 속눈썹 미용 선호도와 만족도}

1) 속눈썹 미용 선호도

속눈썹 미용 선호도를 살펴본 결과는 Table 1 과 같이 나타났 다. 속눈썹 미용사의 중요한 시술 기술은 '속눈썹 디자인의 유 지력' 120 명(46.7\%), 가장 선호하는 속눈썹 모의 종류로는 '실 크 모' 106명(41.2\%)으로 나타났다. 속눈썹 모의 컬 선호도는 'JC컬' 105명(40.9\%)으로 가장 높았고, 속눈썹 모의 굵기로는 
'0.05-0.07 mm' 116 명(45.1\%), 속눈썹 모의 길이는 '10 mm' 94 명(36.6\%), '11 mm' 93명(36.2\%)으로 비슷하게 나타났으 며, 속눈썹 미용의 선호하는 기법으로는 '모근 보호 기법' 81 명 $(31.5 \%)$ 으로 가장 선호하였다.

2) 속눈썹 미용 시술 후 만족도

속눈썹 미용 시술 후 만족도를 살펴본 결과는 Table 2 와 같이 나타났다. 속눈썹 미용 후 가장 만족스럽게 변화된 부분은 '눈 전 체' 128 명(49.8\%)였으며, 시술 후 변화된 모습의 만족도는 '만족 한다' 127 명(49.4\%)으로 나타났다. 속눈썹 미용 후 가장 만족하 는 점은 '눈이 선명해 보인다' 109명(42.4\%)였으며, '눈매를 선 명하게 보이게 하기 위하여' 138 명(53.7\%)가 속눈썹 미용을 하
는 이유로 나타났다. 마스카라 이용 실태에 대하여 연구한 Lee $\&$ Kuh (2003)의 속눈썹 미용 이용 후 만족도와 마스카라 이용 이유의 결과와 일치하였다. 속눈썹 미용 이용 사유는 '기분전환 을 위해' 92 명(35.8\%)였고, 속눈썹 미용의 주된 목적은 '나의 만 족감을 찾기 위해서' 119 명(46.3\%), '아름다움을 위해서' 117 명 (45.5\%) 순으로 나타났다.

\section{2. 속눈썹 미용 선호도 및 시술 후 만족도 차이}

1) 중요한 시술 기술에 따른 시술 후 만족도

속눈썹 미용사의 중요한 시술 기술에 따른 시술 후 만족도 차 이를 확인하기 위해 카이제곱 검정을 실시하였다. 속눈썹 미용 사의 중요한 시술 기술에 따른 시술 후 만족도는 Table 3 과 같이

Table 1. Eyelash beauty treatment preference

\begin{tabular}{|c|c|c|c|}
\hline Division & & Frequency $(\mathrm{N})$ & Percentage (\%) \\
\hline \multirow{5}{*}{ Important skills of eyelash designer } & Eyelash design retention & 120 & 46.7 \\
\hline & Shortened design time & 9 & 3.5 \\
\hline & Design by eye-style & 77 & 30.0 \\
\hline & Natural eyelash damage & 47 & 18.3 \\
\hline & Etc. & 4 & 1.6 \\
\hline \multirow{5}{*}{ Types of eyelash hair } & Silk hair & 106 & 41.2 \\
\hline & Mink hair & 47 & 18.3 \\
\hline & Velvet hair & 60 & 23.3 \\
\hline & Protein hair & 42 & 16.3 \\
\hline & Etc. & 2 & 0.8 \\
\hline \multirow{5}{*}{ Curl of eyelash hair } & $\mathrm{J}$ curl & 44 & 17.1 \\
\hline & $\mathrm{JC}$ curl & 105 & 40.9 \\
\hline & C curl & 100 & 38.9 \\
\hline & $\mathrm{CC}$ curl & 6 & 2.3 \\
\hline & D curl & 2 & 0.8 \\
\hline \multirow{5}{*}{ Thickness of eyelash hair } & $0.05-0.07 \mathrm{~mm}$ & 116 & 45.1 \\
\hline & $0.10 \mathrm{~mm}$ & 105 & 40.9 \\
\hline & $0.15 \mathrm{~mm}$ & 30 & 11.7 \\
\hline & $0.20 \mathrm{~mm}$ & 5 & 1.9 \\
\hline & $0.25 \mathrm{~mm}$ & 1 & 0.4 \\
\hline \multirow{5}{*}{ Length of eyelash hair } & $9 \mathrm{~mm}$ & 40 & 15.6 \\
\hline & $10 \mathrm{~mm}$ & 94 & 36.6 \\
\hline & $11 \mathrm{~mm}$ & 93 & 36.2 \\
\hline & $12 \mathrm{~mm}$ & 28 & 10.9 \\
\hline & Etc. & 2 & 0.8 \\
\hline \multirow{5}{*}{ Eyelash technique } & One-to-one technique & 76 & 29.6 \\
\hline & Speed technique & 31 & 12.1 \\
\hline & Hair root protection technique & 81 & 31.5 \\
\hline & Augmentation techniques & 39 & 15.2 \\
\hline & D technique & 30 & 11.7 \\
\hline Total & & 257 & 100.0 \\
\hline
\end{tabular}


Table 2. Eyelash beauty treatment satisfaction level

\begin{tabular}{|c|c|c|c|}
\hline Division & & Frequency (N) & Percentage (\%) \\
\hline \multirow{5}{*}{ The most satisfies change part } & All eyes & 128 & 49.8 \\
\hline & Whole face & 42 & 16.3 \\
\hline & Whole body & 1 & 0.4 \\
\hline & All image & 82 & 31.9 \\
\hline & Etc. & 4 & 1.6 \\
\hline \multirow{4}{*}{ Satisfaction on the changed } & Very satisfied & 72 & 28.0 \\
\hline & Satisfied & 127 & 49.4 \\
\hline & Middle & 55 & 21.4 \\
\hline & Not satisfied & 3 & 1.2 \\
\hline \multirow{5}{*}{ The most satisfied part } & Eyes look pretty & 63 & 24.5 \\
\hline & Eyes look bigger & 31 & 12.1 \\
\hline & The eyes are clear & 109 & 42.4 \\
\hline & Lashes look long & 23 & 8.9 \\
\hline & The eyelashes look rich & 31 & 12.1 \\
\hline \multirow{5}{*}{ Reasons for getting eyelash beauty } & To make eyes look bigger & 50 & 19.5 \\
\hline & To have long and rich eyelash & 54 & 21.0 \\
\hline & To make your eyes look sharp & 138 & 53.7 \\
\hline & Unconsciously & 5 & 1.9 \\
\hline & Etc. & 10 & 3.9 \\
\hline \multirow{5}{*}{ Cause of treatment } & To substitute makeup & 88 & 34.2 \\
\hline & On weekends & 13 & 5.1 \\
\hline & Periodically & 28 & 10.9 \\
\hline & For the recreation & 92 & 35.8 \\
\hline & On important occasions & 36 & 14.0 \\
\hline \multirow{5}{*}{ Purpose of treatment } & For beauty & 117 & 45.5 \\
\hline & To find my satisfaction & 119 & 46.3 \\
\hline & For social activities & 10 & 3.9 \\
\hline & Routinely & 7 & 2.7 \\
\hline & Etc. & 4 & 1.6 \\
\hline Total & & 257 & 100.0 \\
\hline
\end{tabular}

나타났다. 그 결과, 가장 만족스럽게 변화된 부분과 시술 후 변 화된 모습의 만족도에서 유의미한 차이가 존재하였으나 속눈썹 미용 후 가장 만족하는 점과 속눈썹 미용을 하는 이유, 이용 사 유, 시술 목적에 따른 차이는 유의수준 $5 \%$ 에서 유의미하지 않았 다.

먼저 가장 만족스럽게 변화된 부분에서는 '눈 전체'에서 중요 한 시술 기술이 속눈썹 디자인의 유지력(50.0\%), 눈매에 따른 디 자인(53.2\%), 자연 속눈썹의 손상도(46.8\%)로 가장 많이 응답하 였지만, '얼굴 전체'에서 속눈썹 디자인의 유지력(22.5\%)과 자연 속눈썹의 손상도(23.4\%)가 눈매에 따른 디자인(5.2\%)에 비해 더 많이 응답하여 그 차이가 존재하였다 $\left(\chi^{2}=12.706 ; p<0.05\right)$. 시 술 후 변화된 모습의 만족도에서 중요한 시술 기술이 눈매에 따
른 디자인(50.6\%), 속눈썹 디자인의 유지력(48.3\%), 자연속눈 썹의 손상도(40.4\%)의 모든 경우에 '만족한다'로 가장 많이 응답 하였지만, 속눈썹 디자인의 유지력(35.0\%)과 자연속눈썹의 손상 도(31.9\%)의 경우 눈매에 따른 디자인(18.2\%)에 비해서 '매우 만 족한다'를 더 많이 응답하여 그 차이가 존재하였다 $\left(\chi^{2}=12.677\right.$; $p<0.05)$.

2) 선호하는 속눈썹 모 종류에 따른 시술 후 만족도

선호하는 속눈썹 모 종류에 따른 시술 후 만족도는 Table 4와 같이 나타났다. 선호하는 속눈썹 모 종류에 따른 시술 후 만족도 의 차이를 확인하기 위해 카이제곱 검정을 실시하였다. 그 결과, 가장 만족스럽게 변화된 부분과 시술 후 변화된 모습의 만족도에 
Table 3. Eyelash beauty treatment satisfaction level based on important skills

\begin{tabular}{|c|c|c|c|c|c|c|c|c|c|c|}
\hline \multirow[b]{2}{*}{ Division } & \multirow[b]{3}{*}{ All eyes } & \multicolumn{6}{|c|}{ Important skills of eyelash designer } & \multirow{2}{*}{\multicolumn{2}{|c|}{ Total }} & \multirow{3}{*}{$x^{2}(p)$} \\
\hline & & \multicolumn{2}{|c|}{$\begin{array}{l}\text { Eyelash design } \\
\text { retention }\end{array}$} & \multicolumn{2}{|c|}{$\begin{array}{l}\text { Design by } \\
\text { eye-style }\end{array}$} & \multicolumn{2}{|c|}{$\begin{array}{l}\text { Natural eyelash } \\
\text { damage }\end{array}$} & & & \\
\hline \multirow{4}{*}{$\begin{array}{l}\text { The most } \\
\text { satisfies } \\
\text { change part }\end{array}$} & & 60 & $50.0 \%$ & 41 & $53.2 \%$ & 22 & $46.8 \%$ & 123 & $50.4 \%$ & \\
\hline & Whole face & 27 & $22.5 \%$ & 4 & $5.2 \%$ & 11 & $23.4 \%$ & 42 & $17.2 \%$ & \multirow{3}{*}{$\begin{array}{c}12.706 \\
(0.048)\end{array}$} \\
\hline & Whole body & 31 & $25.8 \%$ & 30 & $39.0 \%$ & 13 & $27.7 \%$ & 74 & $30.3 \%$ & \\
\hline & All image & 2 & $1.7 \%$ & 2 & $2.6 \%$ & 1 & $2.1 \%$ & 5 & $2.0 \%$ & \\
\hline \multirow{4}{*}{$\begin{array}{l}\text { Satisfaction } \\
\text { on the } \\
\text { changed }\end{array}$} & Very satisfied & 42 & $35.0 \%$ & 14 & $18.2 \%$ & 15 & $31.9 \%$ & 71 & $29.1 \%$ & \multirow{4}{*}{$\begin{array}{r}12.677 \\
(0.048\end{array}$} \\
\hline & Satisfied & 58 & $48.3 \%$ & 39 & $50.6 \%$ & 19 & $40.4 \%$ & 116 & $47.5 \%$ & \\
\hline & Middle & 18 & $15.0 \%$ & 24 & $31.2 \%$ & 12 & $25.5 \%$ & 54 & $22.1 \%$ & \\
\hline & Not satisfied & 2 & $1.7 \%$ & 0 & $0.0 \%$ & 1 & $2.1 \%$ & 3 & $1.2 \%$ & \\
\hline \multirow{5}{*}{$\begin{array}{l}\text { The most } \\
\text { satisfied } \\
\text { part }\end{array}$} & Eyes look pretty & 36 & $30.0 \%$ & 13 & $16.9 \%$ & 13 & $27.7 \%$ & 62 & $25.4 \%$ & \multirow{5}{*}{$\begin{array}{r}8.438 \\
(0.392)\end{array}$} \\
\hline & Eyes look bigger & 15 & $12.5 \%$ & 9 & $11.7 \%$ & 4 & $8.5 \%$ & 28 & $11.5 \%$ & \\
\hline & The eyes are clear & 48 & $40.0 \%$ & 38 & $49.4 \%$ & 17 & $36.2 \%$ & 103 & $42.2 \%$ & \\
\hline & Lashes look long & 7 & $5.8 \%$ & 9 & $11.7 \%$ & 6 & $12.8 \%$ & 22 & $9.0 \%$ & \\
\hline & The eyelashes look rich & 14 & $11.7 \%$ & 8 & $10.4 \%$ & 7 & $14.9 \%$ & 29 & $11.9 \%$ & \\
\hline \multirow{4}{*}{$\begin{array}{l}\text { Reasons } \\
\text { for getting } \\
\text { eyelash } \\
\text { beauty }\end{array}$} & To make eyes look bigger & 22 & $18.3 \%$ & 17 & $22.1 \%$ & 10 & $21.3 \%$ & 49 & $20.1 \%$ & \multirow{4}{*}{$\begin{array}{c}8.171 \\
(0.226)\end{array}$} \\
\hline & To have long and rich eyelash & 22 & $18.3 \%$ & 16 & $20.8 \%$ & 14 & $29.8 \%$ & 52 & $21.3 \%$ & \\
\hline & To make your eyes look sharp & 69 & $57.5 \%$ & 42 & $54.5 \%$ & 18 & $38.3 \%$ & 129 & $52.9 \%$ & \\
\hline & Unconsciously & 7 & $5.8 \%$ & 2 & $2.6 \%$ & 5 & $10.6 \%$ & 14 & $5.7 \%$ & \\
\hline \multirow{5}{*}{$\begin{array}{l}\text { Cause of } \\
\text { treatment }\end{array}$} & To substitute makeup & 47 & $39.2 \%$ & 23 & $29.9 \%$ & 15 & $31.9 \%$ & 85 & $34.8 \%$ & \multirow{5}{*}{$\begin{array}{l}8.348 \\
(0.400)\end{array}$} \\
\hline & On weekends & 7 & $5.8 \%$ & 2 & $2.6 \%$ & 4 & $8.5 \%$ & 13 & $5.3 \%$ & \\
\hline & Periodically & 16 & $13.3 \%$ & 6 & $7.8 \%$ & 4 & $8.5 \%$ & 26 & $10.7 \%$ & \\
\hline & For the recreation & 37 & $30.8 \%$ & 35 & $45.5 \%$ & 17 & $36.2 \%$ & 89 & $36.5 \%$ & \\
\hline & On important occasions & 13 & $10.8 \%$ & 11 & $14.3 \%$ & 7 & $14.9 \%$ & 31 & $12.7 \%$ & \\
\hline \multirow{4}{*}{$\begin{array}{l}\text { Purpose of } \\
\text { treatment }\end{array}$} & For beauty & 53 & $44.2 \%$ & 36 & $46.8 \%$ & 22 & $46.8 \%$ & 111 & $45.5 \%$ & \multirow{4}{*}{$\begin{array}{l}1.706 \\
(0.945)\end{array}$} \\
\hline & To find my satisfaction & 56 & $46.7 \%$ & 37 & $48.1 \%$ & 20 & $42.6 \%$ & 113 & $46.3 \%$ & \\
\hline & For social activities & 5 & $4.2 \%$ & 2 & $2.6 \%$ & 2 & $4.3 \%$ & 9 & $3.7 \%$ & \\
\hline & Etc. & 6 & $5.0 \%$ & 2 & $2.6 \%$ & 3 & $6.4 \%$ & 11 & $4.5 \%$ & \\
\hline Total & & 120 & $100.0 \%$ & 77 & $100.0 \%$ & 47 & $100.0 \%$ & 244 & $100.0 \%$ & \\
\hline
\end{tabular}

${ }^{*} p<0.05$

서 그 차이가 존재하였다. 속눈썹 미용 후 가장 만족하는 점과 속 눈썹 미용을 하는 이유, 이용 사유, 시술 목적에 따른 차이는 유 의수준 $5 \%$ 에서 유의미하지 않았다.

가장 만족스럽게 변화된 부분에서는 '눈 전체'에서 선호하는 속눈썹 모 종류가 실크 모(59.4\%), 벨벳 모(45.0\%), 밍크 모(44.7\%)의 경우 가장 많이 응답한 반면, 선호하는 속눈썹 모 종류가 단백질 모(45.2\%) 인 경우 가장 만족스럽게 변화된 부분이 '체형 전체'로 가장 많이 응 답하여 그 차이가 존재하였다 $\left(\chi^{2}=26.965 ; p<0.01\right)$. 그리고 시술 후 변화된 모습의 만족도에서 선호하는 속눈썹 모 종류가 실크 모 (52.8\%), 벨벳 모(50.0\%), 단백질 모(47.6\%), 밍크 모(44.7\%)의 모 든 경우에 '만족한다'가 가장 많이 응답하였지만, 실크 모(31.1\%), 밍 크 모(38.3\%), 벨벳 모(26.7\%)의 경우 단백질 모(9.5\%)에 비해서 시 술 후 변화된 모습의 만족도에서 '매우 만족한다'가 더 많이 응답하
여 그 차이가 존재하였다 $\left(\chi^{2}=19.674 ; p<0.05\right)$.

3) 선호하는 속눈썹 모 컬에 따른 시술 후 만족도

선호하는 속눈썹 모 컬에 따른 시술 후 만족도의 차이는 Table 5 에 나타난 바와 같이 가장 만족스럽게 변화된 부분에서 그 차이가 존재하였다. 선호하는 속눈썹 모 컬이 J컬, JC컬, C컬인 모든 경 우 가장 만족스럽게 변화된 부분이 '눈 전체'로 가장 많이 응답하 였지만, 선호하는 속눈썹 모 컬이 C컬의 경우 J컬, JC컬 에 비해 서 가장 만족스럽게 변화된 부분이 '얼굴 전체'가 더 많이 응답하 여 그 차이가 존재하였다 $\left(\chi^{2}=14.736 ; p<0.05\right)$.

4) 선호하는 속눈썹 모 굵기에 따른 시술 후 만족도

선호하는 속눈썹 모 굵기에 따른 시술 후 만족도는 Table 6 과 
Table 4. Eyelash beauty treatment satisfaction level based on preferred types of eyelash hair

\begin{tabular}{|c|c|c|c|c|c|c|c|c|c|c|c|c|}
\hline \multirow{3}{*}{ Division } & & \multicolumn{8}{|c|}{ Types of eyelash hair } & \multirow{2}{*}{\multicolumn{2}{|c|}{ Total }} & \multirow{2}{*}{$x^{2}(p)$} \\
\hline & & \multicolumn{2}{|c|}{ Silk hair } & \multicolumn{2}{|c|}{ Mink hair } & \multicolumn{2}{|c|}{ Velvet hair } & \multicolumn{2}{|c|}{ Protein hair } & & & \\
\hline & All eyes & 63 & $59.4 \%$ & 21 & $44.7 \%$ & 27 & $45.0 \%$ & 16 & $38.1 \%$ & 127 & $49.8 \%$ & \multirow{4}{*}{$\begin{array}{r}26.965 * \\
(0.001)\end{array}$} \\
\hline \multirow{3}{*}{$\begin{array}{l}\text { The most } \\
\text { satisfied } \\
\text { treated part }\end{array}$} & Whole face & 18 & $17.0 \%$ & 10 & $21.3 \%$ & 10 & $16.7 \%$ & 3 & $7.1 \%$ & 41 & $16.1 \%$ & \\
\hline & Whole body & 25 & $23.6 \%$ & 16 & $34.0 \%$ & 22 & $36.7 \%$ & 19 & $45.2 \%$ & 82 & $32.2 \%$ & \\
\hline & All image & 0 & $0.0 \%$ & 0 & $0.0 \%$ & 1 & $1.7 \%$ & 4 & $9.5 \%$ & 5 & $2.0 \%$ & \\
\hline \multirow{4}{*}{$\begin{array}{l}\text { Satisfaction } \\
\text { on the } \\
\text { changed }\end{array}$} & Very satisfied & 33 & $31.1 \%$ & 18 & $38.3 \%$ & 16 & $26.7 \%$ & 4 & $9.5 \%$ & 71 & $27.8 \%$ & \multirow{4}{*}{$\begin{array}{l}19.674 \\
(0.020)\end{array}$} \\
\hline & Satisfied & 56 & $52.8 \%$ & 21 & $44.7 \%$ & 30 & $50.0 \%$ & 20 & $47.6 \%$ & 127 & $49.8 \%$ & \\
\hline & Middle & 17 & $16.0 \%$ & 7 & $14.9 \%$ & 13 & $21.7 \%$ & 17 & $40.5 \%$ & 54 & $21.2 \%$ & \\
\hline & Not satisfied & 0 & $0.0 \%$ & 1 & $2.1 \%$ & 1 & $1.7 \%$ & 1 & $2.4 \%$ & 3 & $1.2 \%$ & \\
\hline Total & & 106 & $100.0 \%$ & 47 & $100.0 \%$ & 60 & $100.0 \%$ & 42 & $100.0 \%$ & 255 & $100.0 \%$ & \\
\hline
\end{tabular}

${ }^{*} p<0.05 ;{ }^{* *} p<0.01$.

Table 5. Eyelash beauty treatment satisfaction level based on preferred curl of eyelash hair

\begin{tabular}{|c|c|c|c|c|c|c|c|c|c|c|}
\hline \multirow{3}{*}{ Division } & & \multicolumn{6}{|c|}{ Curl of eyelash hair } & \multirow{2}{*}{\multicolumn{2}{|c|}{ Total }} & \multirow{3}{*}{$x^{2}(p)$} \\
\hline & & \multicolumn{2}{|c|}{$\mathrm{J}$ curl } & \multicolumn{2}{|c|}{$\mathrm{JC}$ curl } & \multicolumn{2}{|c|}{ C curl } & & & \\
\hline & All eyes & 24 & $54.5 \%$ & 56 & $53.3 \%$ & 46 & $46.0 \%$ & 126 & $50.6 \%$ & \\
\hline \multirow{3}{*}{$\begin{array}{l}\text { The most } \\
\text { satisfied } \\
\text { treated part }\end{array}$} & Whole face & 3 & $6.8 \%$ & 14 & $13.3 \%$ & 22 & $22.0 \%$ & 39 & $15.7 \%$ & \multirow{3}{*}{$\begin{array}{l}14.736 \\
(0.022)\end{array}$} \\
\hline & Whole body & 17 & $38.6 \%$ & 35 & $33.3 \%$ & 27 & $27.0 \%$ & 79 & $31.7 \%$ & \\
\hline & All image & 0 & $0.0 \%$ & 0 & $0.0 \%$ & 5 & $5.0 \%$ & 5 & $2.0 \%$ & \\
\hline \multicolumn{2}{|l|}{ Total } & 44 & $100.0 \%$ & 105 & $100.0 \%$ & 100 & $100.0 \%$ & 249 & $100.0 \%$ & \\
\hline
\end{tabular}

${ }^{*} p<0.05$

Table 6. Eyelash beauty treatment satisfaction level based on preferred thickness of eyelash hair

\begin{tabular}{|c|c|c|c|c|c|c|c|c|c|c|c|c|}
\hline \multirow{2}{*}{ Division } & & \multicolumn{8}{|c|}{ Thickness of eyelash hair } & \multirow{2}{*}{\multicolumn{2}{|c|}{ Total }} & \multirow{2}{*}{$x^{2}(p)$} \\
\hline & & \multicolumn{2}{|c|}{$0.05-0.07 \mathrm{~mm}$} & \multicolumn{2}{|c|}{$0.10 \mathrm{~mm}$} & \multicolumn{2}{|c|}{$0.15 \mathrm{~mm}$} & \multicolumn{2}{|c|}{$0.20 \mathrm{~mm}$} & & & \\
\hline \multirow{4}{*}{$\begin{array}{l}\text { Satisfaction } \\
\text { on the } \\
\text { changed }\end{array}$} & Very satisfied & 31 & $26.7 \%$ & 27 & $25.7 \%$ & 12 & $40.0 \%$ & 2 & $40.0 \%$ & 72 & $28.1 \%$ & \multirow{4}{*}{$\begin{array}{c}29.928^{* *} \\
(0.000)\end{array}$} \\
\hline & Satisfied & 55 & $47.4 \%$ & 58 & $55.3 \%$ & 11 & $36.7 \%$ & 3 & $60.0 \%$ & 127 & $49.6 \%$ & \\
\hline & Middle & 30 & $25.9 \%$ & 20 & $19.0 \%$ & 4 & $13.3 \%$ & 0 & $0.0 \%$ & 54 & $21.1 \%$ & \\
\hline & Not satisfied & 0 & $0.0 \%$ & 0 & $0.0 \%$ & 3 & $10.0 \%$ & 0 & $0.0 \%$ & 3 & $1.2 \%$ & \\
\hline \multirow{5}{*}{$\begin{array}{l}\text { Cause of } \\
\text { treatment }\end{array}$} & $\begin{array}{l}\text { To substitute } \\
\text { makeup }\end{array}$ & 36 & $31.0 \%$ & 42 & $40.0 \%$ & 9 & $30.0 \%$ & 0 & $0.0 \%$ & 87 & $34.0 \%$ & \multirow{5}{*}{$\begin{array}{c}28.671^{* *} \\
(0.004)\end{array}$} \\
\hline & On weekends & 3 & $2.6 \%$ & 7 & $6.7 \%$ & 3 & $10.0 \%$ & 0 & $0.0 \%$ & 13 & $5.1 \%$ & \\
\hline & Periodically & 7 & $6.0 \%$ & 11 & $10.5 \%$ & 8 & $26.6 \%$ & 2 & $40.0 \%$ & 28 & $10.9 \%$ & \\
\hline & For the recreation & 50 & $43.1 \%$ & 34 & $32.3 \%$ & 5 & $16.7 \%$ & 3 & $60.0 \%$ & 92 & $35.9 \%$ & \\
\hline & $\begin{array}{l}\text { On important } \\
\text { occasions }\end{array}$ & 20 & $17.3 \%$ & 11 & $10.5 \%$ & 5 & $16.7 \%$ & 0 & $0.0 \%$ & 36 & $14.1 \%$ & \\
\hline Total & & 116 & $100.0 \%$ & 105 & $100.0 \%$ & 30 & $100.0 \%$ & 5 & $100.0 \%$ & 256 & $100.0 \%$ & \\
\hline
\end{tabular}

${ }^{* *} p<0.01 ;{ }^{* * *} p<0.001$.

같이 나타났다. 그 결과, 시술 후 변화된 모습의 만족도와 이용 사 유에서 그 차이가 존재하였다. 먼저 시술 후 변화된 모습의 만족도 에서 선호하는 속눈썹 모 굵기가 $0.05-0.07 \mathrm{~mm}, 0.10 \mathrm{~mm}, 0.20$ $\mathrm{mm}$ 인 경우 '만족한다'로 가장 많은 응답을 했지만, 선호하는 속눈썹 모 굵기가 $0.15 \mathrm{~mm}, 0.20 \mathrm{~mm}$ 의 경우 $0.05-0.07 \mathrm{~mm}, 0.10 \mathrm{~mm}$ 에 비해서 시술 후 변화된 모습의 만족도에서 '매우 만족한다'가 더
많이 나와 그 차이가 존재하였다 $\left(\chi^{2}=29.928 ; p<0.001\right)$. 이용 사유에서 선호하는 속눈썹 모 굵기가 $0.10 \mathrm{~mm}, 0.15 \mathrm{~mm}$ 의 경우, ' 메이크업을 대체하기 위하여' 시술을 한다고 응답한 사람이 가장 많 은 반면, 선호하는 속눈썹 모 굵기가 $0.05-0.07 \mathrm{~mm}, 0.20 \mathrm{~mm}$ 인 경우, '기분전환을 위하여' 시술을 한다고 응답한 사람이 가장 많아 그 차이가 존재하였다 $\left(\chi^{2}=28.671 ; p<0.01\right)$. 
Table 7. Eyelash beauty treatment satisfaction level based on preferred length of eyelash hair

\begin{tabular}{|c|c|c|c|c|c|c|c|c|c|c|c|c|}
\hline \multirow{3}{*}{ Division } & \multirow[b]{3}{*}{ All eyes } & \multicolumn{8}{|c|}{ Length of eyelash hair } & \multirow{2}{*}{\multicolumn{2}{|c|}{ Total }} & \multirow{3}{*}{$x^{2}(p)$} \\
\hline & & \multicolumn{2}{|c|}{$9 \mathrm{~mm}$} & \multicolumn{2}{|c|}{$10 \mathrm{~mm}$} & \multicolumn{2}{|c|}{$11 \mathrm{~mm}$} & \multicolumn{2}{|c|}{$12 \mathrm{~mm}$} & & & \\
\hline & & 26 & $65.0 \%$ & 48 & $51.1 \%$ & 45 & $48.4 \%$ & 9 & $32.1 \%$ & 128 & $50.2 \%$ & \\
\hline \multirow{3}{*}{$\begin{array}{l}\text { The most } \\
\text { satisfied } \\
\text { treated part }\end{array}$} & Whole face & 3 & $7.5 \%$ & 10 & $10.6 \%$ & 21 & $22.6 \%$ & 7 & $25.0 \%$ & 41 & $16.0 \%$ & \multirow{3}{*}{$\begin{array}{l}19.000^{*} \\
(0.025)\end{array}$} \\
\hline & Whole body & 9 & $22.5 \%$ & 35 & $37.2 \%$ & 27 & $29.0 \%$ & 11 & $39.3 \%$ & 82 & $32.2 \%$ & \\
\hline & All image & 2 & $5.0 \%$ & 1 & $1.1 \%$ & 0 & $0.0 \%$ & 1 & $3.6 \%$ & 4 & $1.6 \%$ & \\
\hline \multirow{4}{*}{$\begin{array}{l}\text { Satisfaction } \\
\text { on the } \\
\text { changed }\end{array}$} & Very satisfied & 9 & $22.5 \%$ & 19 & $20.2 \%$ & 28 & $30.1 \%$ & 16 & $57.1 \%$ & 72 & $28.2 \%$ & \multirow{4}{*}{$\begin{array}{l}21.310^{*} \\
(0.011)\end{array}$} \\
\hline & Satisfied & 20 & $50.0 \%$ & 53 & $56.4 \%$ & 47 & $50.5 \%$ & 7 & $25.0 \%$ & 127 & $49.8 \%$ & \\
\hline & Middle & 11 & $27.5 \%$ & 22 & $23.4 \%$ & 16 & $17.2 \%$ & 4 & $14.3 \%$ & 53 & $20.8 \%$ & \\
\hline & Not satisfied & 0 & $0.0 \%$ & 0 & $0.0 \%$ & 2 & $2.2 \%$ & 1 & $3.6 \%$ & 3 & $1.2 \%$ & \\
\hline \multirow{5}{*}{$\begin{array}{l}\text { Cause of } \\
\text { treatment }\end{array}$} & $\begin{array}{l}\text { To substitute } \\
\text { makeup }\end{array}$ & 23 & $57.5 \%$ & 31 & $33.0 \%$ & 28 & $30.1 \%$ & 6 & $21.4 \%$ & 88 & $34.5 \%$ & \multirow{5}{*}{$\begin{array}{r}38.317^{* * *} \\
(0.000)\end{array}$} \\
\hline & On weekends & 0 & $0.0 \%$ & 4 & $4.3 \%$ & 7 & $7.5 \%$ & 2 & $7.1 \%$ & 13 & $5.1 \%$ & \\
\hline & Periodically & 3 & $7.5 \%$ & 4 & $4.3 \%$ & 12 & $12.9 \%$ & 9 & $32.1 \%$ & 28 & $11.0 \%$ & \\
\hline & For the recreation & 12 & $30.0 \%$ & 40 & $42.6 \%$ & 35 & $37.6 \%$ & 4 & $14.3 \%$ & 91 & $35.7 \%$ & \\
\hline & $\begin{array}{l}\text { On important } \\
\text { occasions }\end{array}$ & 2 & $5.0 \%$ & 15 & $16.0 \%$ & 11 & $11.8 \%$ & 7 & $25.0 \%$ & 35 & $13.7 \%$ & \\
\hline Total & & 40 & $100.0 \%$ & 94 & $100.0 \%$ & 93 & $100.0 \%$ & 28 & $100.0 \%$ & 255 & $100.0 \%$ & \\
\hline
\end{tabular}

${ }^{* *} p<0.05 ;{ }^{* * *} p<0.001$.

Table 8. Eyelash beauty treatment satisfaction level based on preferred eyelash technique

\begin{tabular}{|c|c|c|c|c|c|c|c|c|c|c|c|c|c|c|}
\hline \multirow{3}{*}{ Division } & \multirow[b]{3}{*}{$\begin{array}{l}\text { To substitute } \\
\text { makeup }\end{array}$} & \multicolumn{10}{|c|}{ Eyelash technique } & \multirow{2}{*}{\multicolumn{2}{|c|}{ Total }} & \multirow{3}{*}{$x^{2}(p)$} \\
\hline & & \multicolumn{2}{|c|}{$\begin{array}{l}\text { One-to-one } \\
\text { technique }\end{array}$} & \multicolumn{2}{|c|}{$\begin{array}{l}\text { Speed } \\
\text { technique }\end{array}$} & \multicolumn{2}{|c|}{$\begin{array}{l}\text { Hair root } \\
\text { protection } \\
\text { technique }\end{array}$} & \multicolumn{2}{|c|}{$\begin{array}{l}\text { Augmentation } \\
\text { techniques }\end{array}$} & \multicolumn{2}{|c|}{ D technique } & & & \\
\hline & & 34 & $44.7 \%$ & 14 & $45.2 \%$ & 18 & $22.2 \%$ & 11 & $28.2 \%$ & 11 & $36.7 \%$ & 88 & $34.2 \%$ & \\
\hline \multirow{4}{*}{$\begin{array}{l}\text { Cause of } \\
\text { treatment }\end{array}$} & On weekends & 0 & $0.0 \%$ & 0 & $0.0 \%$ & 5 & $6.2 \%$ & 4 & $10.3 \%$ & 4 & $13.3 \%$ & 13 & $5.1 \%$ & \multirow{4}{*}{$\begin{array}{l}33.019^{* *} \\
(0.007)\end{array}$} \\
\hline & Periodically & 11 & $14.5 \%$ & 0 & $0.0 \%$ & 8 & $9.9 \%$ & 5 & $12.8 \%$ & 4 & $13.3 \%$ & 28 & $10.9 \%$ & \\
\hline & $\begin{array}{l}\text { For the } \\
\text { recreation }\end{array}$ & 23 & $30.3 \%$ & 11 & $35.5 \%$ & 33 & $40.7 \%$ & 17 & $43.6 \%$ & 8 & $26.7 \%$ & 92 & $35.8 \%$ & \\
\hline & $\begin{array}{l}\text { On important } \\
\text { occasions }\end{array}$ & 8 & $10.5 \%$ & 6 & $19.4 \%$ & 17 & $21.0 \%$ & 2 & $5.1 \%$ & 3 & $10.0 \%$ & 36 & $14.0 \%$ & \\
\hline Total & & 76 & $100.0 \%$ & 31 & $100.0 \%$ & 81 & $100.0 \%$ & 39 & $100.0 \%$ & 30 & $100.0 \%$ & 257 & $100.0 \%$ & \\
\hline
\end{tabular}

${ }^{* *} p<0.01$.

5) 선호하는 속눈썹 모 길이에 따른 시술 후 만족도

선호하는 속눈썹 모 길이에 따른 시술 후 만족도는 Table 7과 같이 나타났다. 선호하는 속눈썹 모 길이에 따른 시술 후 만족도 는 가장 만족스럽게 변화된 부분, 시술 후 변화된 모습의 만족도, 이용 사유에서 그 차이가 존재하였다. 먼저 가장 만족스럽게 변화 된 부분에서 선호하는 속눈썹 모 길이가 $9 \mathrm{~mm}, 10 \mathrm{~mm}, 11 \mathrm{~mm}$ 인 경우 '눈 전체'로 가장 많이 응답한 반면, $12 \mathrm{~mm}$ 인 경우 '체형 전체'가 가장 많이 응답하여 그 차이가 존재하였다 $\left(\chi^{2}=19.000\right.$; $p<0.05)$. 시술 후 변화된 모습의 만족도에서 선호하는 속눈썹 모 길이가 $9 \mathrm{~mm}, 10 \mathrm{~mm}, 11 \mathrm{~mm}$ 인 경우 '만족한다'가 가장 많이 응답한 반면, $12 \mathrm{~mm}$ 인 경우 '매우 만족한다'가 가장 많이 응답
하여 그 차이가 존재하였다 $\left(\chi^{2}=21.310 ; p<0.05\right)$. 이용시기에 서 선호하는 속눈썹 모 길이가 $10 \mathrm{~mm}, 11 \mathrm{~mm}$ 인 경우 이용 사 유가 '기분전환을 위하여'가 가장 많이 응답한 반면, 선호하는 속 눈썹 모 길이가 $9 \mathrm{~mm}$ 인 경우 '메이크업을 대체하기 위하여', 선 호하는 속눈썹 모 길이가 $12 \mathrm{~mm}$ 인 경우 '정기적으로'가 가장 많 이 응답하여 그 차이가 존재하였다 $\left(\chi^{2}=39.317 ; p<0.001\right)$.

\section{6) 선호하는 속눈썹 미용 기법에 따른 시술 후 만족도}

선호하는 속눈썹 미용 기법에 따른 시술 후 만족도의 차이를 확인하기 위해 카이제곱 검정을 실시하였다. 그 결과, Table 8과 같이 나타났으며 시술 시기에서 그 차이가 존재하였다. 즉, 이용 
사유에서 선호하는 속눈썹 모 기법이 원-투-원 기법, 스피드 속 눈썹 기법, $\mathrm{D}$ 기법의 경우 '메이크업을 대체하기 위하여'가 가장 많 이 응답한 반면, 모근 보호 기법, 증모 기법인 경우 '기분전환을 위 하여'가 가장 많이 응답하여 그 차이가 존재하였다 $\left(\chi^{2}=33.019\right.$; $p<0.01)$.

\section{Conclusion}

본 연구는 속눈썹 미용에 대한 선호도와 만족도를 알아보기 위 해 2016년 9월 5일부터 9월 20일까지 부산 지역에 거주하는 20 대 전문대학에 재학중인 미혼 여성을 대상으로 257 부의 설문지 를 조사하였으며, 통계 분석 방법으로는 SPSS 22.0 프로그램을 이용하였다.

속눈썹 미용 선호도와 만족도를 살펴보기 위하여 빈도분석을 실시하였다. 속눈썹 미용 선호도를 살펴 본 결과, 속눈썹 미용 사의 중요한 시술 기술은 '속눈썹 디자인의 유지력'으로 나타났 으며, 이는 시술 후 아름다운 눈매를 유지하는 것을 우선으로 여 기는 것으로 사료된다. 가장 선호하는 속눈썹 모의 종류로는 속 눈썹 미용 시 가장 자연스럽고 인모와 가장 흡사한 '실크 모', 컬 의 선호도는 어색하지 않고 자연스러운 'JC컬', 속눈썹 모의 굵기 로는 가늘고 얇아서 자연스러운 '0.05-0.07 mm', 모의 길이는 '10 mm', '11 mm'를 선호하는 것으로 나타났다. 이는 인위적인 눈매보다는 자연스럽고 선한 눈매 연출을 원하는 것이라고 사료 되며 자연속눈썹을 그대로 유지하면서 아름다운 눈매를 연출할 수 있는 '모근 보호 기법'을 선호하는 것으로 나타났다.

속눈썹 미용 후 만족도를 살펴 본 결과, 속눈썹 미용 후 가장 만족스럽게 변화된 부분은 '눈 전체', 시술 후 변화된 모습의 만 족도는 '만족한다', 속눈썹 미용 후 가장 만족하는 점은 '눈이 선 명해 보인다', 속눈썹 미용을 하는 이유는 '눈매가 선명하게 보이 게 하기 위하여로 나타났다. 한국 여성의 속눈썹이 숱이 적고 짧 다는 특성 때문에 마스카라의 단점을 보완할 수 있는 속눈썹 미 용을 하는 결과라 판단된다. 속눈썹 미용 이용 시기는 '기분전환 과 메이크업을 대처하기 위하여'이었으며, 속눈썹 미용의 주된 목적은 '나의 만족감을 찾기 위해서'로 나타났다.

속눈썹 미용 시술 후 만족도의 차이를 확인하기 위해 카이제곱 검정 교차분석을 실시하였다. 중요한 시술 기술에 따른 시술 후 만족도의 차이는 속눈썹 미용 시술 후 가장 만족스럽게 변화된 부분과 시술 후 변화된 모습의 만족도의 차이는 유의미하였으나 속눈썹 미용 후 가장 만족하는 점과 속눈썹 미용을 하는 이유, 이 용 사유, 시술 목적에 따른 차이는 유의수준 $5 \%$ 에서 유의미하지 않았다. 선호하는 속눈썹 모 종류에 따른 시술 후 만족도는 가장 만족스럽게 변화된 부분과 시술 후 변화된 모습의 만족도에서 그 차이가 존재하였다. 속눈썹 미용 후 가장 만족하는 점과 속눈썹
미용을 하는 이유, 이용 사유, 시술 목적에 따른 차이는 유의미 하지 않았다.

선호하는 속눈썹 모의 컬에 따른 시술 후 만족도의 차이는 J 컬, JC컬, C컬로 시술 했을 때 가장 만족스럽게 변화된 부분에서 이미지와 얼굴 전체에 비해 눈 전체의 변화를 가장 만족하는 것 으로 사료된다. 또한, 선호하는 속눈썹 모 굵기에 따른 시술 후 만족도의 차이는 시술 후 변화된 모습의 만족도와 이용 사유에서 그 차이가 존재하였다. 자연스러운 눈매 연출로 평상시 메이크업 을 대처하기 위해 $0.10 \mathrm{~mm}$ 굵기로 시술하는 반면 $0.20 \mathrm{~mm}$ 굵 기는 기분전환을 위해 시술하는 것으로 나타났다.

선호하는 속눈썹 모 길이에 따른 시술 후 만족도의 차이는 가 장 만족스럽게 변화된 부분, 시술 후 변화된 모습의 만족도, 이 용 사유에서 그 차이가 존재하였다. $9 \mathrm{~mm}, 10 \mathrm{~mm}, 11 \mathrm{~mm}$ 를 시술했을 때 가장 만족스럽게 변화된 부분이 '눈 전체', 시술 후 변화된 모습의 만족도를 '만족한다'라고 응답한 반면, $12 \mathrm{~mm}$ 로 시술하였을 때 '체형 전체', '매우 만족한다'가 가장 많이 응답되 었다. $9 \mathrm{~mm}$ 를 시술하였을 때는 메이크업을 대처하는 수단으로 평상시에도 자연스러운 미를 추구하기 위함인 것으로 사료된다. 선호하는 속눈썹 미용 기법에 따른 시술 후 만족도의 차이는 이 용 사유에서 나타났는데 메이크업을 대처하기 위해 자연스러운 원-투-원 기법과 바쁜 일상생활에서 시술 시간을 줄이기 위한 스피드 속눈썹 기법을 많이 선호하는 반면, 기분전환을 위해 풍 성하고 인위적인 느낌을 줄 수 있는 증모 기법을 많이 선호하는 것으로 사료된다.

본 연구는 속눈썹 미용에 관련된 연구가 전무한 상황이기에 연 구결과에 의의가 있다고 할 수 있겠으나, 속눈썹 미용에 관련된 선행연구가 부족하여 비교하고 논의할 만한 자료가 충분하지 못 하였고 조사대상이 부산 지역에 거주하는 20 대 여성을 대상으로 한정되어 있어 연구 결과를 전체 속눈썹 미용 선호도와 만족도에 대한 광범위한 해석으로 일반화하기에는 다소 무리가 있다. 후속 연구에서는 연구대상자의 다양한 연령대와 여러 지역을 대상으 로 한 속눈썹 미용 선호도 및 만족도에 관한 연구가 이루어지기 를 기대한다.

\section{References}

Ahn HM, Cho JA. The effect of female's make-up and nail design on the likeness. The Journal of the Korean Society of Make-up Design, 2: 335-346, 2006.

Amano Y, Nishiwaki Y. National survey on eyelash extensions and their related health problems. Japanese Journal of Hygiene, 68: 168-174, 2013.

Amano Y, Sugimoto $\mathrm{Y}$, Sugita M. Ocular disorders due to 
eyelash extensions. Cornea, 31: 121-125, 2012.

An SJ. Effects of eyelash beauty art on substance perception and eyesight. Journal of the Korean Society of Beauty and Art, 6: 181-198, 2005.

Choi MR, Kim YS, Yeom KS, Park SH, Kim YM. The beauty make-up. Yelim Publishing, Seoul, pp22-44, 2004.

Cohen JL. Enhancing the growth of natural eyelashes: the mechanism of bimatoprost-induced eyelash growth. Dermatologic Surgery, 36: 1361-1371, 2010.

Gandelman M. A technique for reconstruction of eyebrows and eyelashes. Seminars in Plastic Surgery, 19: 153158, 2005.

Go EJ. Eyelash extension manual book. Youngrim Publishing, Seoul, pp12-132, 2015.

Jamieson RC. Eyelash dye (lash-lure) dermatitis with conjunctivitis. The Journal of the American Medical Association, 101: 1560, 1933.

Jang YY, Yoo TS. Sustainable makeup design using environment-friendly materials. Journal of Korea Design Forum, 37: 199-210, 2012.

Kang GH, Park GW. All of eyelash extension. Sidaeedu Publishing, Seoul, pp2-155, 2016.

Kim GY, Kim GO, Kim HJ, Park SH, Park YH, Bae JH, Song SY, Oh YK, Jang YS, Han KA. Dermatology. Soomoonsa Publishing, Paju, pp86-93, 2001.

Kim JH, An NK, Kim MY. Special procurements beauty. Crown Publishing, Seoul, pp110-147, 2017.
Kim JY. Bobbi Brown makeup manual. Joongang M\&B, Seoul, pp120-121, 2009. (Brown B. 2008.)

Kwon SY. Touch. Openhouse Publishing, Seoul, pp49-61, 2012.

Kwon HY, Kwon HJ, Shin GO, An SR, Youn MS. Dermatology. MeDiCEAN Publishing, Paju, pp35-39, 2012.

Lee HJ, Jeon YS, Jo GM, Jo JA, Han JA. The make-up. Yelim Publishing, Seoul, pp26-80, 2001.

Lee KA, Kuh JM. A study on the patterns of mascara usage in Korean women. Journal of the Korean Society of Beauty and Art, 4: 45-61, 2003.

Lee $\mathrm{KH}$, Han CJ. Usage of, preference for, and satisfaction with extended eyelashes and false eyelashes in adult women. Asian Journal of Beauty and Cosmetology, 15: 299-309, 2017.

Lim MA. A study for eyelash make up. Journal of the Korean Society of Beauty and Art, 8: 79-90, 2007.

Seol HJ. A study on a safe method of hair extension: with an emphasis on the eyelash. Journal of the Korean Society of Beauty and Art, 9: 54-65, 2008.

Song KM, Min KH. Effects of cosmetic eyelash extension on eyelashes health problems and evaluation of common eyelash nutritional supplements. Asian Journal of Beauty and Cosmetology, 12: 211-216, 2014.

Umar S. Eyelash transplantation using leg hair by follicular unit extraction. Plastic and Reconstructive Surgery Global Open, 3: 324, 2015. 


\section{국문초록}

\section{속눈썹 미용에 대한 선호도 및 만족도}

권태일 ${ }^{1}$, 허혜순 ${ }^{*}$

${ }^{1}$ 고신대학교 보건환경학부, 부산, 한국

${ }^{2}$ 동부산대학교 웨딩산업과, 부산, 한국

목적: 본 연구는 속눈썹 미용에 대한 선호도 및 만족도를 조사하여, 속눈썹 선호도에 따른 만족도의 차이를 알아보고자 한다. 방 법: 부산 지역에 거주하는 20 대 미용전공 대학생 257명을 대상으로 2016년 9월 5일부터 9월 20일까지 설문조사를 시행하였다. 속 눈섭 미용 선호도와 만족도를 알아보기 위하여 빈도분석을 실시하였고, 시술 후 만족도 차이를 알아보기 위하여 카이제곱 검정 $\left(\chi^{2}\right)$ 교차분석을 실시하였다. 결과: 속눈썹 미용 선호도를 살펴본 결과, 미용사의 중요한 시술 기술은 속눈썹 디자인 유지력이었으며 가 장 선호하는 종류는 실크 모, JC컬, 모의 굵기는 0.05-0.07 mm, 모의 길이는 $10,11 \mathrm{~mm}$, 모근 보호 기법으로 나타났다. 속눈썹 미 용 시술 후 대부분 만족하는 것으로 나타났으며, 속눈썹 미용을 하는 이유는 '눈이 선명해 보이기 위해서'로 나타났다. 속눈썹 미용 을 하는 이유는 '기분전환을 위해', 속눈썹 미용의 주된 목적은 '나의 만족감을 찾기 위해서'로 나타났다. 속눈썹 미용 선호도 및 시술 후 만족도의 차이를 알아본 결과, 중요한 시술 기술, 선호하는 속눈썹 모의 종류, 모 컬, 모 굵기, 모 길이, 모 기법에 따른 만족도의 차이는 유의미하였다. 결론: 얼굴 전체의 이미지를 좌우하는 눈은 다양한 속눈썹 재료와 속눈썹 미용 기법들을 통해 연출할 수 있 다. 추후에는 속눈썹 미용이 현장에서 더욱 효과적으로 활용되고, 다양한 연령대와 여러 지역을 대상으로 고객의 선호도와 만족도 를 파악하는 연구를 제안한다.

핵심어: 속눈썹, 속눈썹 디자인, 속눈썹 미용, 선호도, 만족도

\section{참고문헌}

강경희, 박기원. 프로가 되는 속눈썹 연장. 시대에듀, 서울, $\mathrm{pp} 2-155,2016$.

고은정. 속눈썹 연장술 교본서. 영림미디어, 서울, pp12-132, 2015.

권선영. 터치: 메이크업으로 당신의 마음을 터치하다. 오픈하우스, 서울, pp49-61, 2012.

권혜영, 권혜진, 신규옥, 안선례, 윤미숙. NEW 피부과학. 메디시언, 파주, pp35-39, 2012.

김기연, 김광옥, 김현주, 박선희, 박영호, 배정하, 송선영, 오유경, 장예선, 한경아. 피부과학. 수문사, 파주, pp86-93, 2001.

김정희, 안나경, 김미영. 누구나 쉽게 하는 특수미용. 크라운출판사, 서울, pp110-147, 2017.

김진영. 바비 브라운 메이크업 매뉴얼. 중앙 M\&B, 서울, pp120-121, 2009. (브라운 바비, 2008.)

설현진. 안전한 모발연장술에 관한 연구: 속눈썹 중심으로. 한국인체미용예술학회지, 9: 54-65, 2008.

송경미, 민경훈. 속눈썹 연장이 속눈썹 손상도에 미치는 영향과 속눈썹 영양제의 효능. 아시안뷰티화장품학술지, 12 :

211-216, 2014.

안소정. 속눈썹(Eyelashes) 미용이 물체 인식과 시력에 미치는 영향. 한국인체미용예술학회지, 6: 181-198, 2005.

안혜민, 조진아. 여성의 메이크업과 네일디자인이 호감도에 미치는 영향. 한국메이크업디자인학회지, 2: $355-346$,

2006.

이강아, 구자명. 우리나라 여성의 마스카라 이용 실태에 관한 연구. 한국인체미용예술학회지, 4: 45-61, 2003.

이경화, 한채정. 성인여성의 속눈썹 연장 및 일회용 속눈썹 이용실태, 선호도 및 만족도 연구. 아시안뷰티화장품학술지,

15: 299-309, 2017.

이현주, 전연숙, 조고미, 조진아, 한정아. 메이크업. 예림, 서울, pp26-80, 2001.

임미애. 속눈썹 화장에 관한 연구. 한국인체미용예술학회지, 8: 79-90, 2007. 
장윤영, 유태순. 친환경 소재를 이용한 지속가능한 메이크업 디자인. 한국디자인포럼, 37: 199-210, 2012.

최민령, 김예성, 염경숙, 박선희, 김영미. 뷰티 메이크업. 예림, 서울, pp22-44, 2004. 


\section{中文摘要}

\section{眼戝毛美容的偏好度和满意度}

权泰一 ${ }^{1}$, 许惠顺 $^{2^{*}}$

${ }^{1}$ 高神大学保健环境学院, 釜山, 韩国

2东福山大学婚庆产业学院, 釜山, 韩国

目的: 通过调查眼睫毛美容的偏好度和满意度, 根据眼睫毛偏好来探索其满意度差距。方法: 采用统计系统 Statistical Package for the Social Science（SPSS）22.0调查257名居住在釜山地区的20多岁美容专业大学生。为了 调查眼睫毛美容的偏好度和满意度, 实施了频度分析; 并为了调查眼睫毛美容后的满意度差距, 实施了卡方检 验 $\left(x^{2}\right)$ 交叉分析。结果: 调查眼睫毛美容偏好度结果显示, 美容师最为重要的技术是眼睫毛的设计维持, 最 为喜好的种类是丝绸睫毛、JC卷; 眼睫毛的厚度为 $0.05-0.07 \mathrm{~mm}$; 毛的长度为 $10,11 \mathrm{~mm}$ 。首选的睫毛技术 是毛根保护法。大多数参与者对他们的睫毛美容感到满意, 并且寻求睫毛美容的原因是为了使他们的眼睛看起 来很清晰。眼睫毛美容的原因是为了转换情绪, 最终主要目的是为了满足自己的自我形象。眼眏毛美容的偏好 度和美容之后满意度差距结果显示, 根据睫毛美容技术、眼睫毛种类、卷曲、粗度、长度、以及毛根保护法其 满意度差距具有统计学意义。结论: 影响整个脸部形象的眼睛可以通过各种睫毛材料和睫毛美容技术来演出。 为眼睫毛美容在现场更加有效地被利用, 我们提出了对各个年龄和地区的客户偏好度和满意度的研究。

关键词: 眼睫毛, 睫毛设计, 睫毛美容, 偏好度, 满意度 